\title{
O Comércio Atacadista Carioca (1855-1900): Padrões e Processos Espaciais
}

\section{Wholesale Trade in Rio de Janeiro (1855-1900): Spatial Patterns and Processes}

\author{
Vitor de Araujo Alvesi \\ Prefeitura Municipal do Rio de Janeiro \\ Rio de Janeiro, Brasil
}

\begin{abstract}
Resumo: Na segunda metade do século XIX começa a se desenrolar com mais intensidade a separação entre os usos do solo na cidade do Rio de Janeiro, processo que norteia o presente artigo. O objetivo é participar dessa discussão através da análise dos padrões e processos espaciais relacionados aos comerciantes atacadistas, que serão vistos nos anos de 1855 e 1900. Partimos da premissa de que os atacadistas, mais do que meros responsáveis pelo depósito e comercialização de produtos "em grosso", cumprem ainda o papel da intermediação comercial. A articulação entre as escalas espaciais da produção e do consumo não deve ser subestimada, principalmente num mundo onde ainda predominam a dificuldade e a lentidão nas comunicações. Por fim, a cadeia comercial de exportação do café será vista como um caso à parte e terá mais dois recortes temporais intermediários, possibilitando uma análise espacial mais detalhada.
\end{abstract}

Palavras-chave: Comércio atacadista carioca; Processos espaciais; Geografia Histórica

Abstract: In the second half of the Nineteenth Century the separation of land uses in the City of Rio de Janeiro began to unfold with greater intensity and this process is analyzed through spatial patterns involving wholesale merchants between 1855 and 1900. Our premise is that wholesalers are not just responsible for the storage and marketing of bulk products but also play an important role in commercial intermediation. The relationship between the spatial scales of production and consumption should not be underestimated, especially in a world still characterized by difficult and slow communications. The marketing chain of coffee exports is presented as a special case and is analyzed in two sub-periods, which allow for more detailed spatial analysis.

Keywords: Wholesale trade, Spatial processes, Historical Geography

\section{Apresentação, Motivações e Dificuldades}

Este artigo é fruto da Dissertação de Mestrado por mim defendida junto ao PPGG/ UFRJ no ano de 2011'. E essa não teria sido possível sem o Professor Mauricio de Almeida Abreu. É muito bom que agora vejamos, em diferentes atividades científicas, uma crescente valorização da linha de pesquisa da qual ele foi um dos precursores no Brasil. Com menos brilho e muita gratidão, continuamos agora a retraçar outras geografias do passado.

i Professor da Secretaria Municipal de Educação e da rede particular de ensino. vitualves@gmail.com 
Alves, V. A.

A possibilidade de estudar um tema pouco explorado na geografia e na história de início não foi tão animadora, mas acabou se tornando com o tempo; o resultado foi um trabalho que, a despeito dos problemas, conseguiu reunir algumas contribuições. Uma delas é uma rápida reflexão teórica sobre a Geografia Histórica² ${ }^{2}$ A segunda, uma revisão bibliográfica sobre o comércio atacadista, possibilitou que abordássemos pontos como a negligência com a temática, a evolução no seu tratamento dentro da geografia urbana e a tentativa de uma melhor delimitação de sua natureza. As funções a ele relacionadas, como veremos brevemente, são mais importantes do que tem se suposto normalmente.

Mas é outra contribuição que aqui nos interessa e da qual deriva a presente publicação. Trata-se da análise do setor atacadista carioca na segunda metade dos oitocentos, que mais amplamente se insere na evolução urbana e comercial do Rio de Janeiro. Este artigo é, portanto, essencialmente empírico e vai apresentar uma parte da discussão e dos resultados obtidos a partir do levantamento cartográfico. Por razões óbvias, não será disponibilizado o extenso conjunto de 25 mapas, 10 modelos comparativos e 71 tabelas do comércio atacadista carioca; a exposição sobre os procedimentos metodológicos utilizados para tal também será o mais breve possível. Com isso, a problematização sobre a elaboração e a interpretação cartográfica e sobre o uso das fontes históricas ficará para outra oportunidade.

Escolhas como essas, na verdade, foram a maior dificuldade enfrentada na execução do artigo. Primeiramente, pela complicada seleção dos elementos a serem tratados, que foram pensados respeitando outra ordem estrutural. Depois, por não podermos tornar muito longa esta interlocução, que (espera-se!) ainda sim deve ser capaz de apresentar uma síntese internamente coerente.

\section{Objetivo, Questão Central e a Natureza do Comércio Atacadista}

A segunda metade do século XIX tem profunda relevância para os que se interessam pela evolução urbana da cidade do Rio de Janeiro. É ao longo destas décadas que começa a se desenrolar o processo de separação entre os usos do solo, eixo que norteia o presente artigo. Em sentido amplo, o estudo sobre esse processo considera as funções residencial, manufatureira/industrial e comercial. Este trabalho, todavia, está restrito a esta última e tem como objetivo analisar os padrões e processos espaciais de um setor específico: o comércio atacadista. Sabidamente, isso não significa alijar da análise as outras funções urbanas e o outro ramo do setor comercial, o varejista.

A mistura quase total nos usos do solo da cidade do Rio de Janeiro, típica do espaço urbano carioca no período colonial, deve ser relativizada quando pensamos a segunda metade do século XIX - conforme têm mostrado as pesquisas no campo da geografia histórica carioca. Em uma cidade que conhece um franco crescimento físico e demográfico e um processo de modernização condizente com seu status de capital, a lógica capitalista ganha intensidade e o espaço urbano passa apresentar tendências mais visíveis de especialização. Assim, áreas de maior nível de especialização funcional passam a contrastar com aquele aglomerado urbano que, espremido entre os morros do Castelo, Santo Antônio, São Bento e Conceição, amalgamava as diversas funções urbanas. Mas qual foi o papel que o setor atacadista desempenhou ao longo do processo de separação dos usos do solo no Rio de Janeiro oitocentista?

Para começarmos a responder esta questão é necessário lançar um olhar mais cuidadoso sobre a atividade atacadista e, de fato, muito poucos têm se dedicado a essa tarefa. A relativa negligência com o tema nos parece estranha se admitirmos que esse setor 
é um dos apoios do capitalismo comercial e industrial, à medida que possibilita uma circulação de mercadorias cada vez maior em âmbito local, regional e global. Na geografia, a produção sobre os atacadistas não acompanha o grande número de trabalhos teóricos e empíricos que, na literatura brasileira e internacional, privilegiam o comércio varejista. Lembremos que uma das mais consagradas teorias em geografia urbana - a das localidades centrais, de Walter Christaller (1933) - ignora a localização do comércio por atacado, um problema que derivou da ausência quase total de uma literatura geográfica específica. O passar das décadas, todavia, não foi capaz de impedir o silêncio e como denuncia Corrêa (2000), ainda há uma geografia histórica brasileira do comércio atacadista a ser feita.

Partimos da premissa de que os atacadistas, mais do que meros responsáveis pelo depósito e comercialização de produtos "em grosso" (função mais comumente identificada) cumprem ainda o papel da intermediação comercial. Como mostram os trabalhos de Vance Jr. (1970) e Heidingsfield \& Blankenship (1957), a importância dos intermediadores (comissários, corretores, representantes de firmas de exportação e importação etc.) não deve ser subestimada, principalmente num mundo onde ainda predominam a dificuldade e a lentidão nas comunicações. Trata-se de uma indispensável função de articulação entre as escalas espaciais da produção e do consumo. É partir deles, por exemplo, que a cidade do Rio de Janeiro se conecta à região cafeeira fluminense e escoa a produção direcionada aos mercados estrangeiros; do mesmo modo, máquinas têxteis e produtos manufaturados produzidos no exterior podem entrar na capital do país para, em parte, serem distribuídas a outros portos brasileiros. Foram as próprias necessidades impostas pela distância geográfica entre os produtores e o consumidor final que fizeram surgir o agente de comércio3. Para Vance Jr. (1970) a introdução do agente como um terceiro elemento (onde antes só havia produtores e compradores) é considerada uma das mudanças críticas na geografia econômica: é a partir disso que a economia local se torna parte de uma economia regional mais ampla, não se devendo negligenciar o caráter de pioneirismo proporcionado por essa expansão de horizontes.

As duas funções do comércio atacadista podem ser vistas isoladamente, mas devem ser pensadas também a partir das relações que mantêm entre si. Ao considerá-las, percebemos que a estrutura interna das cadeias comerciais é mais ampla e complexa do que normalmente se supõe. Articulando agentes de intermédio a serviços de transporte, armazenamento e beneficiamento de mercadorias, a atividade atacadista passa a ser vista como um setor e é apenas assim que conseguimos inseri-la no estudo da separação dos usos do solo e dialogar com processos espaciais caros à cidade capitalista, como a centralização e a coesão de atividades terciárias. Além das questões intra-urbanas, inserimo-nos também em discussões mais amplas, como a evolução da atividade portuária no Rio de Janeiro e o papel da cidade na economia brasileira oitocentista, ligado à consolidação das funções de distribuição para o mercado interno e a polarização de produtos para exportação.

\section{Os Recortes Temporais e a Definição das Classes e Gêneros do Comércio Atacadista}

Optou-se por dois recortes temporais sincrônicos (1855 e 1900) ligados diacronicamente, conforme proposta de Estaville Jr (1991). Isolamos assim o comércio atacadista do restante da totalidade espacial, acompanhando sua evolução ao longo de quase 50 anos. Ao trabalharmos apenas com dois recortes perdemos em detalhamento, que foi maior 
Alves, V. A.

no caso da cadeia comercial do café. Neste caso, são quatro recortes sincrônicos com intervalos de quinze anos (1855, 1870, 1885 e 1900) também unidos diacronicamente.

Já a divisão do setor atacadista é feita a partir de quatro classes, como mostra o Quadro 1. A Classe I é a dos intermediadores; já a segunda, terceira e quarta dizem respeito ao chamado comércio "em grosso", representado pelos armazéns e depósitos. A Classe II traz os "Gêneros Alimentícios e afins", a Classe III os "Gêneros Manufaturados" e a Classe IV os "Gêneros voltados à Construção e à Produção Industrial". Os títulos das classes e dos gêneros respeitaram as nomenclaturas da documentação primária. Cada uma das quatro classes foi trabalhada de acordo com disponibilidade de dados retirados do Almanak Laemmert, uma espécie de catálogo do Rio de Janeiro no século XIX. Além da localização das atividades terciárias, esse documento disponibiliza muitos outros tipos de informações, sendo um importante instrumento de pesquisa. É importante reparar que alguns gêneros não estão disponíveis para os dois recortes temporais, demonstrando a dificuldade de se trabalhar com as fontes históricas. Vejamos o Quadro I:

Quadro 1 - Classes e gêneros do comércio atacadista carioca (1855 e 1900).

\begin{tabular}{|c|c|c|}
\hline CLASSES & $\begin{array}{l}\text { Gêneros disponíveis nos dois } \\
\text { recortes temporais }\end{array}$ & $\begin{array}{l}\text { Gêneros disponíveis em apenas } \\
\text { um dos recortes temporais }\end{array}$ \\
\hline $\begin{array}{l}\text { Classe I: } \\
\text { Agentes } \\
\text { Comerciais }\end{array}$ & $\begin{array}{l}\text { - Comissários de gêneros de } \\
\text { importação e exportação; } \\
\text { - Consignatários de gêneros de } \\
\text { importação e exportação; } \\
\text { - Comissários e consignatários } \\
\text { de gêneros de importação e } \\
\text { exportação; }\end{array}$ & $\begin{array}{ll} & \text { Escritórios de agências } \\
\text { comerciais e corretores } \\
\text { (1855); } \\
\text { - Intermediários não- } \\
\text { especificados de gêneros de } \\
\text { importação e exportação } \\
\text { (1900); } \\
\text { Agentes comerciais, } \\
\text { corretores, representantes de } \\
\text { casas estrangeiras e trapiches } \\
\text { alfandegados (1900); }\end{array}$ \\
\hline $\begin{array}{c}\text { Classe II: } \\
\text { Gêneros } \\
\text { Alimentícios e } \\
\text { afins }\end{array}$ & $\begin{array}{l}\text { - } \quad \text { Armazéns de Açúcar; } \\
\text { - } \quad \text { Armazéns de Farinha de Trigo; } \\
\text { - } \quad \text { Armazéns de Sal; } \\
\text { - } \quad \text { Armazéns de Azeite; } \\
\text { - } \quad \text { Armazéns de secos e } \\
\quad \text { molhados por atacado; }\end{array}$ & $\begin{array}{l}\text { - } \quad \text { Armazéns de Arroz (1855); } \\
\text { - } \quad \text { Armazéns de tapioca, goma e } \\
\text { - } \quad \text { Araruta (1855); } \\
\text { - } \quad \text { Alimentares (1855); } \\
\text { Armazéns de carne seca } \\
\text { (1900) }\end{array}$ \\
\hline $\begin{array}{c}\text { Classe III: } \\
\text { Gêneros } \\
\text { Manufaturados }\end{array}$ & $\begin{array}{l}\text { - Armazéns de fazendas; } \\
\text { - } \quad \text { Armazéns de fumo em rolo e } \\
\text { - } \text { Armazéns de Drogas, } \\
\text { Medicamentos e produtos } \\
\text { químicos e farmacêuticos; } \\
\text { - Armazéns de Móveis; }\end{array}$ & $\begin{array}{ll}\text { - } & \text { Armazéns de aguardente; } \\
\text { - } & \text { Armazéns de couros; } \\
\text { - } & \text { Armazéns de sabão e óleos; }\end{array}$ \\
\hline $\begin{array}{c}\text { Classe IV: } \\
\text { Gêneros } \\
\text { voltados à } \\
\text { Construção e à } \\
\text { Produção } \\
\text { Industrial }\end{array}$ & $\begin{array}{l}\text { - Armazéns de Carvão (de } \\
\text { pedra, animal e vegetal); } \\
\text { - Armazéns de ferro, aço e } \\
\text { outros metais; } \\
\text { - Armazéns de madeiras e } \\
\text { materiais para construção civil } \\
\text { e naval; }\end{array}$ & $\begin{array}{l}\text { Armazéns de materiais para } \\
\text { obra (1855); } \\
\text { Depósitos de máquinas e } \\
\text { instrumentos para a indústria } \\
(1900) ;\end{array}$ \\
\hline
\end{tabular}

Fonte: Almanak Laemmert (1855 e 1900). 
A cadeia comercial de exportação do café, por tudo o que representa, será vista como um caso à parte e terá mais dois recortes temporais intermediários (1870 e 1885). Assim como nos casos anteriores, também respeitaremos a dupla função atacadista como critério de divisão para os comerciantes de café. Serão trabalhados os comissários e consignatários de café como representantes da função de intermediação comercial e os armazéns de ensaque como representantes da função de armazenagem.

\section{Construindo a Análise Espacial: o Comércio Atacadista Carioca na Segunda Metade do Século XIX}

\section{Breve contextualização e diálogo com a história econômica}

Segundo Galvão (1992), o Rio de Janeiro - comprimido entre o mar e a montanha, ladeado por praias, restingas, baixadas parcialmente pantanosas e florestas - teve seu crescimento sempre forjado na luta pelo espaço e na superação das distâncias frente às condições especiais do seu meio físico. Entretanto, é no século XIX que começa a época das grandes transformações no espaço urbano.

Até meados dos oitocentos, a área urbana do Rio de Janeiro ainda tinha como limites a orla marítima paralela à Rua Direita (atual Primeiro de Março) e o Campo de Sant' Anna (se tornando menos densa nesta direção). Lateralmente os limites eram, de um lado, os morros do Castelo, Santo Antônio e Senado; de outro, os morros de São Bento, Conceição e Providência. Esses limites correspondem, grosso modo, às atuais regiões administrativas do Centro e Zona Portuária. E se na primeira metade do século XIX a cidade passa por uma grande expansão demográfica, a maior parte da população carioca ainda tinha que se manter na parte que viria a ser chamada de "centro" como questão de sobrevivência. É apenas na segunda metade do século XIX que a cidade vence definitivamente o problema das distâncias e passa a se expandir de modo contínuo e denso, como indica Bernardes (1959). Para Abreu (2006 [1987]), o ano de 1870 é um marco divisório na história da evolução urbana do Rio de Janeiro. De acordo com o autor, a fase compreendida entre este ano e 1902, representa, para a história do Rio de Janeiro a primeira fase de expansão acelerada da malha urbana, com destaque para a atuação conjunta de bondes e trens.

Essa expansão física da cidade, baseada nos sistemas de transportes, era acompanhada pela expansão de outros serviços de consumo coletivo destinados a atender as necessidades básicas da população - como água, esgoto e iluminação. Com mostra Lamarão (1991), esses serviços reestruturaram o deslocamento de homens e mercadorias, definindo um novo contexto que ampliava consideravelmente as possibilidades de atuação do capital. Além da influência nos sistemas técnicos, a atuação capitalista se fazia sentir em outras frentes. A projeção da cidade como grande centro exportador, por exemplo, deu-se através de relações cujos montantes e trâmites exigiam um porte bem maior do que aquele conhecido no período colonial (Lobo, 1978). Vejamos mais de perto algumas questões relativas à evolução da função comercial.

A primeira delas diz respeito ao crescimento de sua importância. Na segunda metade do período oitocentista, a cidade do Rio de Janeiro continuou a exercer seu papel de escoamento de gêneros primários e ainda se consolidou como centro distribuidor de 
Alves, V. A.

artigos importados através do comércio de cabotagem. O número de estabelecimentos atacadistas citados no Laemmert, por exemplo, quase dobrou entre 1855 e 1900. Se no primeiro ano existiam em torno de 900 firmas voltadas para o atacado na cidade, no segundo recorte já eram mais de 1800 estabelecimentos. A classe mais importante em termos quantitativos foi a dos intermediários comerciais (Classe 1), que apresentou também o maior crescimento entre os dois recortes temporais. Dentre todas as classes, esta era a que consumia menos espaço. Já a Classe 4 (Gêneros voltados à Construção e à Produção Industrial), cujos estabelecimentos necessitavam de mais espaço, foi a que apresentou os menores números absolutos e a menor tendência de crescimento entre 1855 e 1900. Por fim, as quantidades de depósitos nas Classes 2 e 3 (gêneros alimentícios e manufaturados, respectivamente) foram quase as mesmas nos dois anos analisados; a diferença é que na Classe 3 o crescimento foi maior de um ano para outro.

A análise da documentação ${ }^{4}$ mostra ainda que a importância do comércio extrapolava os níveis local e regional. Em 1850, dos 2847 navios que entraram no Brasil, 1125 tiveram como destino o Rio de Janeiro; dentre 2877, 1165 saíram do Rio. Nos outros 18 portos listados, o mais dinâmico era o de Salvador, com apenas 470 navios de entrada e 466 de saída. Segundo Lobo (1978), na virada do século XIX o movimento portuário do Rio de Janeiro esteve entre os três principais das Américas e os quinze maiores do mundo. No montante nacional, o movimento comercial do Rio de Janeiro também era impressionante: em 1855, os valores referentes às importações e exportações na capital respondiam por aproximadamente a metade dos valores totais brasileiros. Em 1888, a proporção manteve-se muito alta nas importações (131.369:306 mil réis em um total brasileiro de 260.998:859) embora, nas exportações, começasse a ganhar força a tendência que iria prevalecer a partir da virada para o século XX. Dos 212.592:272 mil réis conseguidos com as exportações, menos de um terço (95.752:919 mil) era proveniente do Rio de Janeiro. Retomaremos o assunto mais a frente, quando tratarmos isoladamente do café.

Analisando os principais produtos da alfândega carioca (e mesmo se considerarmos o total brasileiro), percebemos ainda uma enorme diferença entre as pautas de importação e exportação. De um lado, as exportações são pouco diversificadas, enquanto as importações são bem mais variadas e menos concentradas em termos de valores. Para encurtar este tópico, deixaremos de lado a comparação quantitativa detalhada de cada um dos gêneros que compõe as quatro classes do setor atacadista. Passemos ao começo da análise espacial propriamente dita.

\section{As tendências gerais: os padrões espaciais predominantes}

Esta parte tem intuito de tentar organizar os atacadistas em um mesmo setor ${ }^{5}$, cuja unidade se funda, entre outras coisas, nas regularidades espaciais. Interessa-nos identificar as principais áreas ao longo das quais esteve localizado o setor atacadista carioca na segunda metade do século XIX, buscando entender os padrões que "unem" os anos de 1855 e 1900 .

Em 1855, dentre as mais importantes ruas para os atacadistas estão as de São Pedro, Direita, da Alfândega, da Quitanda, do Sabão, da Candelária, das Violas, dos Pescadores, do Rosário e de São Francisco da Prainha. No ano de 1900, as ruas de São Pedro, Pri- 
meiro de Março (Direita), General Câmara (Sabão) e Alfândega se mantiveram no grupo das mais significativas e as ruas do Rosário, de Teophilo Ottoni (Violas), da Quitanda, do Hospício, da Candelária e Visconde de Inhaúma (Pescadores) reaparecem com força. As novidades são as grandes concentrações nas ruas da Saúde, dos Ourives, do Ouvidor e da Gamboa. A primeira e a última, mais imediatas à zona trapicheira, merecem um olhar mais atento. O mapa na figura 1 sintetiza as regularidades que ligam os dois recortes temporais, um padrão de localização que marca toda a segunda metade do século XIX:

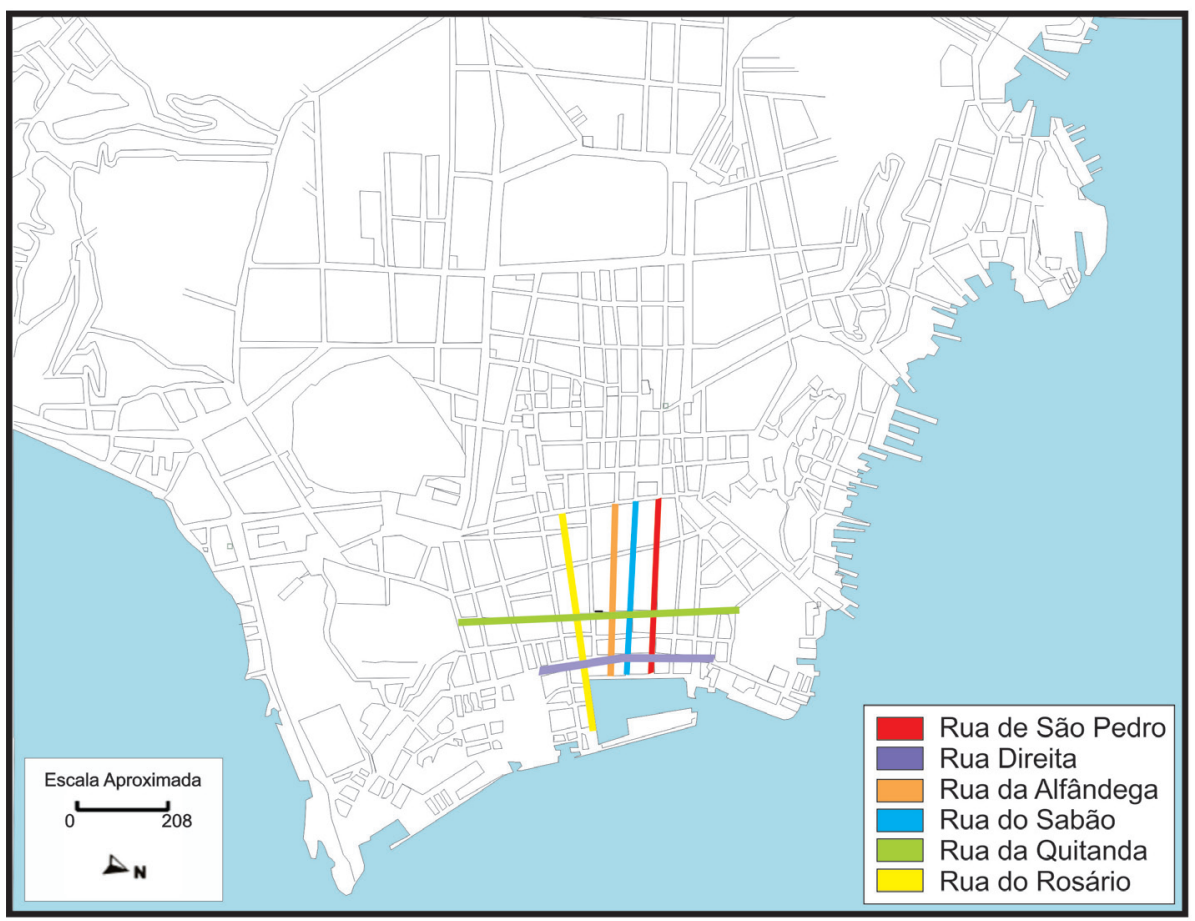

Figura 1 - Principais ruas do comércio por atacado no Rio de Janeiro (1855 e 1900) . Organizado pelo autor. Base cartográfica: Motta (2001).

A identificação das principais ruas, entretanto, não é suficiente para delimitar as tendências gerais do comércio atacadista carioca. Considerando que os estabelecimentos muitas vezes estão localizados em apenas uma parte da rua, ou seja, que existem quarteirões onde a concentração é maior, é preciso ir além desta primeira análise. Utilizou-se o artifício de dividir o espaço em outras unidades, capazes de complementar o quadro espacial mais geral; aqui chamaremos estas unidades espaciais de áreas, que serão representadas mais à frente (Figuras 2 e 3).

A primeira dessas áreas tem como limites as ruas Direita e da Quitanda (ao sul e ao norte); lateralmente, os limites são as ruas de Bragança e do Rosário (a leste e a oeste). A segunda área tem como limites a rua da Quitanda e dos Ourives (ao sul e ao norte) e as ruas dos Pescadores e do Rosário (a leste e a oeste). Em 1900, percebemos a manutenção 
Alves, V. A.

da área 1 como a mais dinâmica da cidade em relação ao comércio por atacado; a área 2, por sua vez, ganha mais importância do que no primeiro recorte, apresentando tendências maiores de concentração. Pode-se notar ainda que o aumento no número de estabelecimentos atacadistas na cidade do Rio de Janeiro é acompanhado de uma expansão no alcance espacial, nos permitindo identificar a presença de, pelo menos, mais seis áreas.

Dentre essas novas áreas de atuação marcante, destaca-se aquela limitada ao sul e ao norte pelas ruas dos Ourives e Uruguaiana, e a leste e a oeste pelas ruas de Teófilo Ottoni (das Violas) e do Ouvidor, respectivamente. Trata-se da área 3. Já a área 4 está circunscrita ao polígono limitado pela rua Uruguaiana e o Campo de Santana (a sul e ao norte) e pelas ruas de São Joaquim e Sete de Setembro (a leste e a oeste) e juntamente com as três anteriores está expressa abaixo:

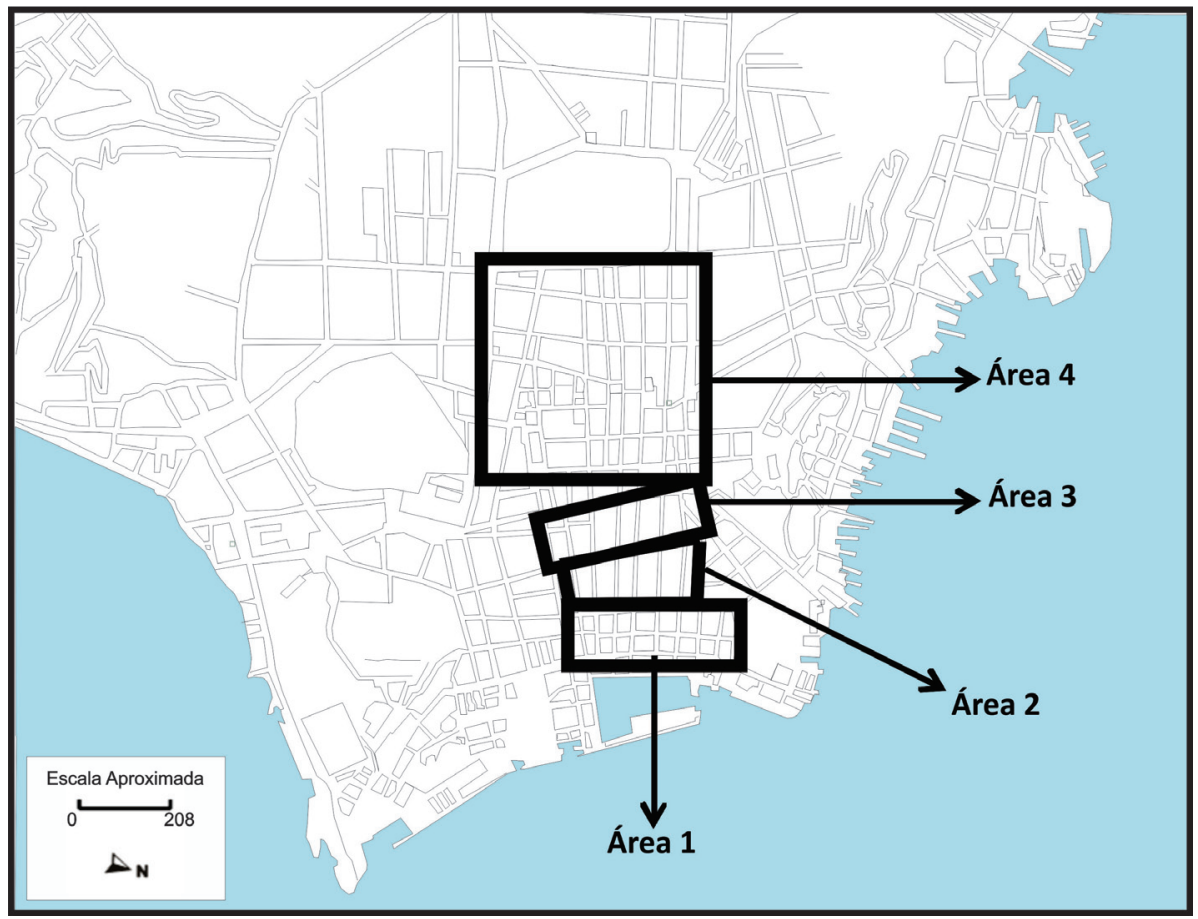

Figura 2 - Comércio atacadista carioca (áreas 1, 2, 3 e 4).

Organizado pelo autor. Base cartográfica: Motta (2001).

As áreas 5, 6, 7 e 8 ainda que bem mais timidamente, completam as tendências gerais em 1900. A área 5 é limitada pela praça XV de novembro e pelo largo da Carioca (ao sul e ao note) e pelas ruas do Ouvidor e de São José (a leste e a oeste). A sexta se localiza nas imediações da rua do Mercado e do Comércio. A área 7 é limitada ao sul pela rua Fresca e ao norte por parte da rua da Ajuda. A leste, o limite é a Praça XV e a oeste, a outra parte da rua da Ajuda. Por fim, a área 8 se estende pela costa leste, que vai do morro de São Bento até o saco da Gamboa, passando pelo morro da Saúde. Vejamos: 


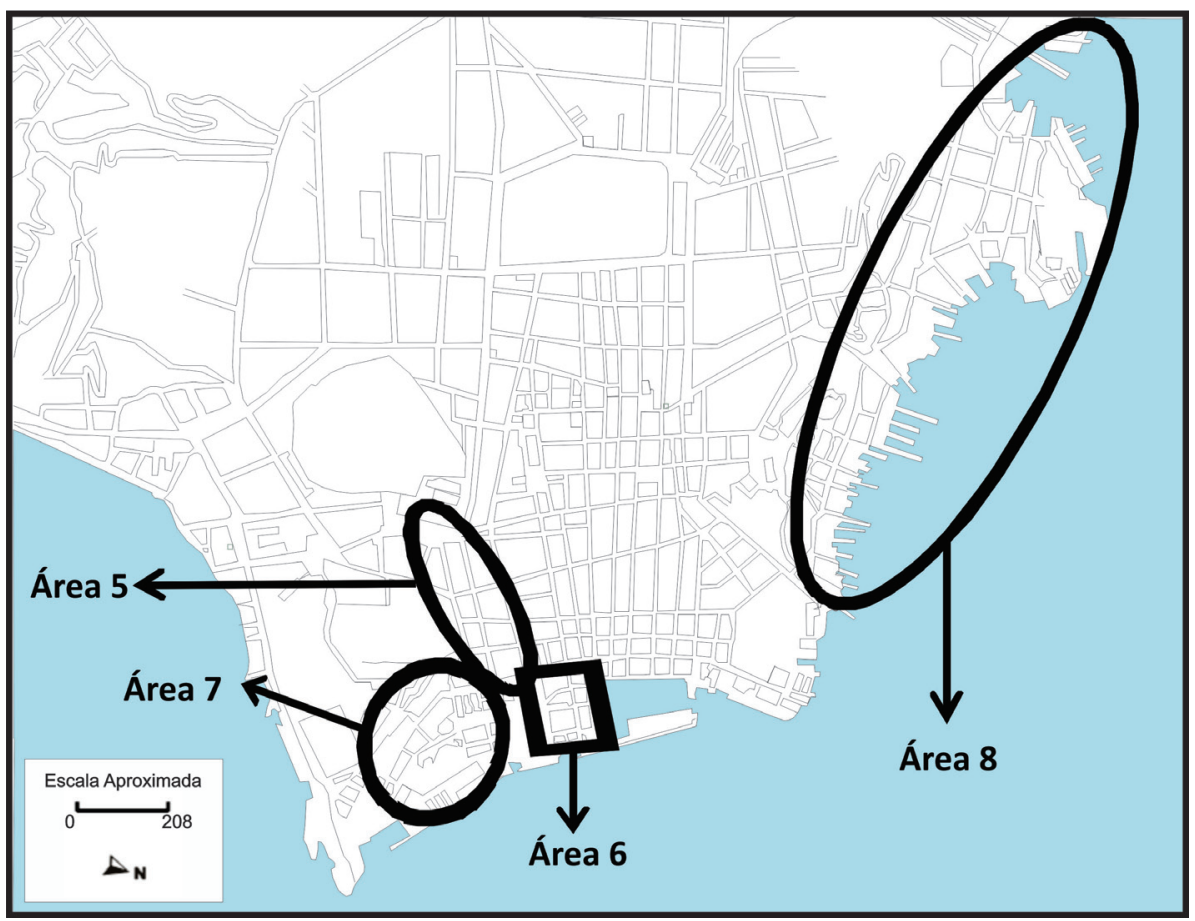

Figura 3 - Comércio atacadista carioca - áreas 5, 6, 7 e 8.

Organizado pelo autor. Base cartográfica: Motta (2001).

\section{Diálogo com a geografia urbana}

O conceito de centralização ${ }^{6}$ nos interessa particularmente nesta etapa. Reflexo da separação dos usos do solo, a formação de uma área central deve ser vista como um dos mais importantes indicativos do fortalecimento capitalista no espaço urbano.

Entre 1855 e 1900, é possível perceber uma tendência geral de aglomeração da atividade atacadista, largamente concentrada nos limites de nosso recorte espacial. No primeiro corte temporal, isso não chega a ser fator de diferenciação, já que a cidade estava praticamente restrita a esses limites. Em 1900, porém, a concentração nesta parte da cidade - que já vê ocupadas outras freguesias mais longínquas - passa a ser mais importante, seguindo a mesma tendência do comércio varejista apontada por Motta (2001). Analisando o comportamento do setor secundário no período analisado, o autor conclui que o processo de centralização se fazia empurrando as unidades fabris para a periferia ou áreas mais distantes (como São Cristóvão) com terrenos ainda disponíveis e com certa quantidade de casarões que poderiam ser reaproveitados para a utilização de instalações industriais. Por último, ainda apura que os serviços foram os que mais apresentaram aumento de atividades e comportamento centralizador, chegando em alguns casos a se localizar de maneira quase especializada no espaço urbano. No caso da exportação do café, veremos que isso acontece de maneira muito clara e que a segunda metade do século XIX é o período-chave nesse desenrolar. 
Alves, V. A.

As áreas 1 e 2 são as que talvez mais reflitam a tendência de centralização em questão. Repare-se que nelas estão presentes as seis principais ruas do comércio por atacado em 1855 e 1900, a saber: ruas de São Pedro, Direita (Primeiro de Março), Alfândega, Sabão (General Câmara), Quitanda e Rosário. Aqui, de fato, estamos diante do "núcleo" atacadista na segunda metade do século XIX, não coincidentemente o eixo mais dinâmico do setor terciário entre 1870 e 1900; novamente com Motta (2001) este tem como limites as ruas Direita e da Quitanda. A necessidade dos atacadistas se manterem perto de onde estavam os estabelecimentos varejistas por eles abastecidos nos parece bastante clara.

Concomitantemente à expulsão da função residencial, a expansão horizontal do setor terciário é válida quando analisamos os atacadistas separadamente. As áreas 3 e 4 representam o crescimento em direção ao Campo de Santana, ou seja, para "fora" da chamada "Cidade Velha". As áreas 5, 6 e 7, por sua vez, definiam-se pela influência de uma importante área de desembarque de mercadorias na cidade, uma localização eficiente sobretudo para artigos importados que abasteciam as adjacências de pontos comerciais como o Mercado, a praça XV e as áreas 1, 2 e 3.

Embora nosso recorte espacial apresente as características apontadas por Corrêa (1996 [1979]) - a aglomeração de atividades terciárias e a facilidade de acesso em relação às outras partes da cidade - é perigoso afirmar que já exista uma área central "propriamente dita". Era ainda muito significativa a presença de atividades bastante diversificadas em contiguidade e de edifícios multifuncionais. Se podemos, com propriedade, afirmar que a segunda metade do século XIX é um período-chave na evolução do que Murphy \& Vance (1954) chamaram de hard core, por outro lado é necessário reconhecer que na cidade do Rio de Janeiro a separação nos usos do solo ainda não havia se concretizado inteiramente. No caso dos atacadistas, estes ainda sequer se separaram totalmente dos varejistas. A ausência dessa repartição é um dos elementos que impede a visualização da chamada Zona Periférica do Centro. Tanto na conceituação de Horwood \& Boyce (1959), quanto em outras anteriormente formuladas (como a "Zona em transição", a "Área cinzenta" ou a "Zona de obsolescência"), o isolamento dos depósitos atacadistas é condição básica para a formação de uma área central bipartida. Em resumo, o mais seguro é afirmar que a centralização de atividades no Rio de Janeiro se apresenta ainda num estágio inicial, em que a pressão exercida pelos preços da terra ainda não foi capaz de expulsar totalmente os atacadistas da área que passou a ser conhecida como centro. Além disso, como já dito, a presença dos atacadistas ao longo das oito áreas (principalmente no caso das áreas 1 a 7) também indica que havia interesse em reduzir os custos de transporte a partir de uma localização próxima aos varejistas. A presença de uma área específica para o comércio a varejo e "livre" dos usos sujos, portanto, teve que esperar até o século XX.

Para Vance (1977, citado por Motta, 2001:17), que propõe um modelo de longa duração para a evolução da área central dividido em seis etapas, o estágio inicial (inception) é caracterizado pelo surgimento do núcleo originário da cidade, via de regra, como ponto de ligação regional com o sistema de comércio a longa distância. Isso parece bastante razoável no caso do Rio de Janeiro oitocentista. O interessante é perceber que o estágio incipiente da centralização de atividades terciárias passa a conviver com pequenas tendências de "periferização", que se confirmam pelo aumento do dinamismo ao longo da área 8. É preciso ficar claro que tais tendências não ocorrem em todo o setor atacadista, mas apenas nos armazéns e depósitos, ou seja, no chamado comércio "em 
grosso". Estes representam a última etapa da cadeia comercial atacadista e são grandes consumidores de espaço, cada vez mais difícil em áreas densamente ocupadas. Quando consideramos o atacado a partir de sua outra função, qual seja, a de intermediador comercial, continua a ser predominante o comportamento centralizador. Tais diferenças funcionais, portanto, refletem-se no espaço geográfico carioca e confirmam a necessidade de um conceito de comércio atacadista que vá além do senso comum, conforme assinalou James Vance Jr. (1970); elas, inclusive, motivam a divisão do próximo item e do último, referente ao estudo da cadeia comercial do café.

\section{A dupla função do comércio por atacado na cidade do Rio de Janeiro}

\section{Os Agentes Comerciais e as Atividades de Exportação e Importação}

Inicialmente, é fundamental relembrar a importância destes comerciantes, que possibilitam as relações entre consumidores e produtores separados por muitos quilômetros de distância. De acordo com Vance Jr. (1970), a teoria explicativa sobre a "internacionalização" capitalista tem ratificado, sobretudo, o papel da evolução tecnológica nos setores de comunicações e transportes, esquecendo da necessidade do agente que opera tais transações. A cidade Rio de Janeiro na segunda metade do século XIX é bom exemplo dessa necessidade: se por um lado ela experimenta novidades impostas pelo capitalismo ao seu sistema técnico, por outro ainda não pode prescindir dos negociantes dedicados à função de integração comercial.

Vejamos rapidamente o caso dos comissários e dos consignatários. Primeiramente, há de se desfazer a ideia de que o comércio por comissão e consignação estava restrito à atividade cafeeira. Na realidade, outros gêneros de exportação - e também importação - eram negociados dessa maneira. Vejamos um exemplo:

Antonio Francisco Guimarães Pinheiro (...) estabelecido com casa de comissões na rua do Hospício, $n^{\circ} 58$ (...) Recebe à consignação mercadorias nacionaes e estrangeiras das províncias de fora do Imperio e aceita quaesquer incumbencias de compras, recebimentos (...) mediante as taxas e fazendo as vantagens mais razoáveis do estylo (Almanak Laemmert, 1855: 459; grifo meu).

Assim, os produtos com os quais estes agentes trabalhavam podiam ser os mais diversos: "Alves e Cruz, consignatários de navios, assucar, carne secca, aguardente, sebo e graxa, r. do Sabão, 46" (Almanak Laemmert, 1855: 458); isso não excluía possíveis atividades especializadas: "Antonio Marques da Silva, comissões de fumo por atacado, rua do Sabão, 57" (Almanak Laemmert, 1855: 459). A função destes agentes era encontrar compradores para os produtos oferecidos pelas firmas que representam com o melhor preço possível. Para tal, recebiam uma comissão ou consignavam parte da venda. É bastante comum que os agentes atuassem nesses dois tipos de agenciamento, muitas vezes tratado como um só.

Além da função intermediadora, os comissários e consignatários podiam estocar nas próprias firmas comissárias as mercadorias, antes de entregá-las: "Araujo e Irmãos, escriptorio commercial e deposito de productos de agricultura, praia dos Mineiros, 45" (Almanak Laemmert, 1855: 458; grifo meu). Isso vem novamente a demonstrar a força que ainda tinha a mistura dos usos - mesmo dentro do setor terciário - e a dificuldade de, na prática, separar 
Alves, V. A.

os atacadistas através de uma dupla função. Dependendo da importância da firma, a quantidade negociada era maior e fazia-se necessário o armazenamento em depósitos maiores.

Os comissários e consignatários também podiam conceder crédito por conta própria. A presença da função financeira (mesmo que ainda não estivesse totalmente separada da função e estocagem) se fazia sentir no espaço urbano carioca a partir de localizações mais "centrais". Isso vale para os dois recortes temporais, como mostra comparativamente a figura 4 - que trata especificamente dos comissários. As área 1 e 2 são as mais dinâmicas nos dois anos e intensificam-se em concentração em 1900. Neste momento, a área 3 também ganha importância, demonstrando o espraiamento do comissariado carioca. A tendência de concentração nas áreas 5 e 6 é bem menor, mas ainda sim contribui para o aumento do alcance espacial dos comissários na cidade do Rio de Janeiro.

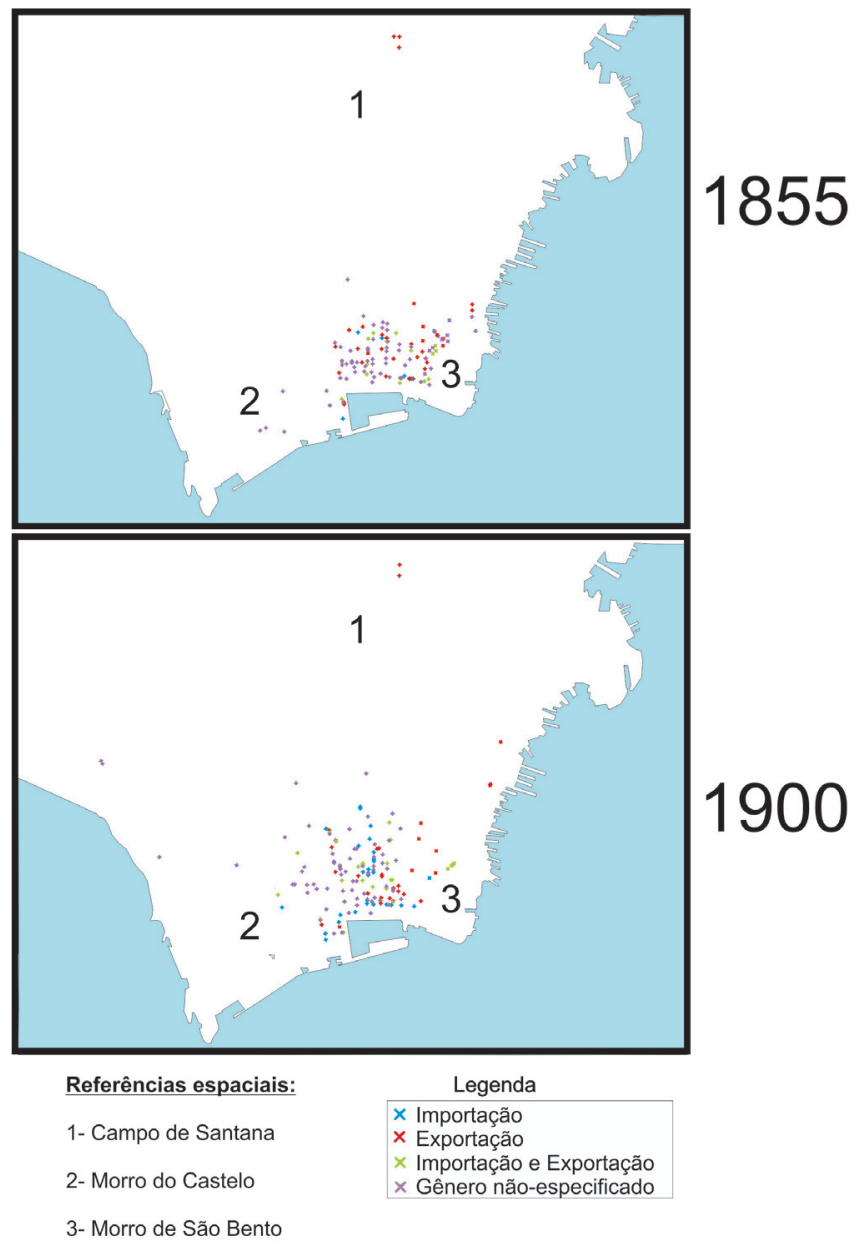

Figura 4 - Comissários de gêneros de exportação e importação em 1855 e 1900. Organizado pelo autor. Base cartográfica: Motta (2001). 
Segundo Heidingsfield \& Blankenship (1957), os representantes têm a função de facilitar a compra ou a venda para os clientes que representa; já o agente de vendas é um intermediário que, sob condições de contrato ao longo prazo, manipula toda a produção de determinado produtor, com liberdade quase total em questões de preço e condições de venda. Em 1900, eles estenderam suas atividades para além da área 1 e passaram a ter concentrações importantes nas áreas 2, 5 e 6. Já os comerciantes que trabalhavam exclusivamente com a consignação se encontram praticamente ausentes no ano de 1900. Considerando o ano de 1855, seu padrão espacial é bastante parecido com o dos comissários. Quanto aos intermediários não-especificados, foi esmagadora a maioria daqueles voltados à importação e espacialmente, eles apresentaram formidáveis concentrações nas áreas 1, 5 e 6 mas, principalmente, nas áreas 2 e 3. A necessidade de encurtar a análise impede-nos de ver mais calmamente essas e outras singularidades dos diversos gêneros que compõe a Classe I. É mais interessante agora apontar que os intermediadores cariocas não se espacializavam a partir de uma divisão territorial do trabalho capaz de definir áreas específicas para importadores e exportadores. Ao contrário, ainda fica clara uma mistura muito significativa entre os serviços de importação e exportação.

\section{Os Armazéns e o Comércio "em grosso"}

A despeito da indisponibilidade de dados que impedem a espacialização de gêneros nos dois recortes, partimos da ideia de que existem características que nos permitem compará-los enquanto um grupo. É ainda preciso atentar à dificuldade de se distinguir com clareza o comércio varejista do atacadista. Esse problema deriva de dois fatos principais. Em primeiro lugar, não é rara a possibilidade de, no mesmo estabelecimento, se verificar os dois tipos de comércio. Depois, pelo fato do Almanak Laemmert não ser a base mais indicada para verificarmos os elementos que Beckman \& Engle (1937 citados por Vance Jr., 1970) definiram como básicos para esta diferenciação: a condição ou o motivo do comprador em fazer a compra, a quantidade de bens envolvidos na transação e o método de operação do negócio. Passemos a uma breve análise do comércio "em grosso", começando pela classe I (Gêneros Alimentícios e afins).

Comparados aos agentes comerciais, há menos tendências de regularidade nos gêneros alimentícios enquanto grupo e algumas permanências só são nítidas quando comparamos os mesmos gêneros em 1855 e 1900. Há um ainda um número menor de ruas com grandes concentrações e em muitos casos se torna difícil até a identificação de um padrão espacial mais nítido. Entretanto, já se nota, na passagem para o ano de 1900, uma tendência de maior dinamismo na área 8, ao longo da zona trapicheira da cidade (praias do Valongo, da Saúde e da Gamboa). Grandes consumidores de espaço, alguns destes armazéns já começam a procurar áreas maiores e mais baratas, embora o adensamento ao longo das áreas 1 e 2 ainda pareça - de maneira geral - muito interessante.

No ano de 1900 é bem maior o espraiamento dos armazéns alimentícios, representado sobretudo por um maior dinamismo nas áreas 2, 3, 6 e 7. Na área 8, as tendências 
Alves, V. A.

de maior concentração passam das imediações do morro de São Bento e largo da Prainha (em 1855) para as proximidades da Praça Municipal e da rua da Saúde (no sentido sul-norte). Dentre os gêneros em questão (açúcar, farinha de trigo, sal, arroz, azeite e carne seca), os mais interessantes a serem analisados separadamente são o primeiro e o último. Ambos eram importados e, em parte, reexportados, embora esta função fosse menos importante. As suas tendências de concentração espacial, deste modo, fazem-nos relativizar a afirmação de Ratcliff (1959, citado por Motta, 2001): segundo este autor, o comércio atacadista voltado para o mercado interno se beneficia menos da companhia de seus competidores, dado que uma firma pode abastecer várias casas comerciais; o mercado de exportação, ao contrário, pressupõe a presença dos concorrentes em contiguidade, facilitando o processo de compra, comparação e seleção. No caso da carne seca, as vantagens oferecidas nas áreas 6 e 7 (próximos do mais importante ponto de entrada de produtos da cidade) parecem mais significativas. Por sua vez, os armazéns de farinha de trigo, sal e arroz, são surpreendentemente menos expressivos (do ponto de vista numérico e do processo de coesão) e é difícil verificar algum padrão espacial ou concentrações mais claras.

Talvez o mais importante para estes três últimos tipos de armazéns fosse se manter próximo aos comerciantes varejistas que abasteciam. É também o caso dos estabelecimentos conhecidos como secos e molhados, que acumulavam as funções de atacadistas e varejistas. Primeiramente, é interessante observar que a enorme presença destes estabelecimentos é indicativa da importância que ainda tinha a função residencial nesta área. Como a própria teoria Christalleriana aponta, o consumidor não se mostra muito disposto a percorrer grandes distâncias para adquirir gêneros corriqueiros, a exemplo dos secos e molhados. Em 1900, todavia, a área 8 (ao longo dos trapiches) passa a ser mais atrativa, sobretudo para os chamados 'mantimentos secos'. A rua da Saúde, neste caso, tem as maior concentração de estabelecimentos.

Assim como no caso dos gêneros alimentícios, é difícil perceber grandes regularidades analisando os gêneros manufaturados e industrializados. Pode-se dizer que a tendência de concentração na área 1 de alguns gêneros contrasta com a de desconcentração de outros, e com um aumento de importância das áreas 3 e 5. Vejamos rapidamente apenas um dos gêneros, os atacadistas de tecidos e fazendas. No primeiro recorte temporal, a enorme presença das chamadas 'fazendas secas de importação' demonstra a importância da importação de tecidos na década de 1850, quando a indústria de tecidos brasileira era ainda incipiente. Neste caso, quase a totalidade dos estabelecimentos está circunscrita à área 1 e mais de $60 \%$ deles concentrada ao longo das ruas da Quitanda e Direita. Em 1900, a presença das 'fazendas por atacado' é incrivelmente alta nas ruas da Alfândega e Primeiro de Março (Direita). Neste momento, a indústria têxtil na cidade já se encontrava consolidada e o mercado interno já não era dependente das importações.

Por fim, os Gêneros voltados à Construção e à Produção Industrial (Figura 5) talvez sejam aqueles que melhor demonstram o aumento de importância da área 8 e um relativo afastamento do núcleo da chamada 'cidade velha'. Ela receberá com força os armazéns que precisam de muito espaço. Vejamos alguns detalhes. 
A importância dos armazéns de carvão, produto que alimentava os fornos das indústrias e das casas cariocas, só pode ser percebida (em relação à quantidade e à concentração espacial) em 1900. A partir daí esse gênero deixa de ser praticamente insignificante para apresentar pequenas concentrações em áreas ao longo da área 8, como na Gamboa e na Praia Formosa (São Cristóvão), que ficou fora da base cartográfica aqui utilizada. As áreas 3 e 5, mais timidamente, também representam o afastamento já citado. Já os armazéns de ferro, aço e outros metais apresentam uma localização importante nas áreas 1 e 2 no ano de 1855, o que se mantém no ano de 1900. Todavia, as maiores concentrações estão nas áreas 3 e 8: na primeira, a rua de Teófilo Ottoni (das Violas) é a mais importante; na segunda, as maiores concentrações estão nas ruas Camerino (da Imperatriz) e da Saúde, logo depois do Mercado Municipal. Os armazéns de madeiras para construção também têm a área 8 como a mais dinâmica. Em 1855, mais da metade deles está concentrada nas ruas de São Francisco da Prainha e da Saúde. As imediações do largo do Paço (áreas 6 e 7) também se mostraram importantes.

Repare-se que em 1900 não há nenhum armazém de madeira ao longo das áreas 1, 2 e 3, algo raro até este momento. As maiores concentrações estão novamente na área 8, nas ruas da Saúde e em São Cristóvão. Nos gêneros restritos a apenas um dos anos. Em 1855, os armazéns de materiais para obra tiveram grande concentração na rua da Prainha, na parte sul da área 8. Novamente, praticamente não há presença nas áreas 1, 2 e 3. A rua da Prainha lidera também a concentração das máquinas e equipamentos voltados à indústria, que tem ainda grandes concentrações nas ruas de Teófilo Otoni e Travessa de Santa Rita, perto do morro de São Bento. Além dessa área, o limite entre as áreas 2 e 3 é o mais dinâmico; a área 8, por sua vez, é representada pela concentração da rua Camerino. 
Alves, V. A.

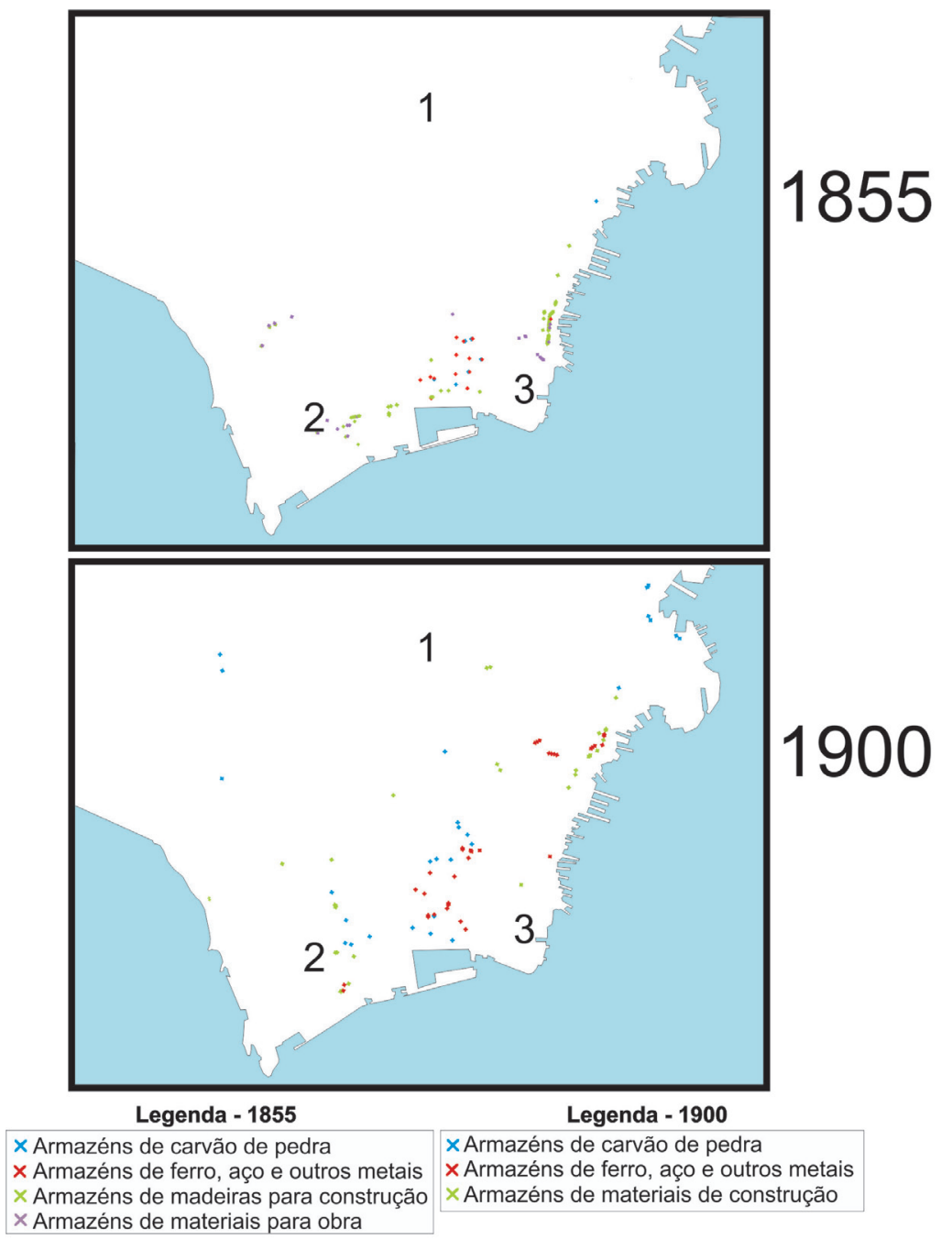

Referências espaciais:

$$
\begin{aligned}
& \text { 1- Campo de Santana } \\
& \text { 2- Morro do Castelo } \\
& \text { 3- Morro de São Bento }
\end{aligned}
$$

Figura 5 - Armazéns de carvão, ferro, madeiras para construção (1855-1900) e de materiais para obra (1855). Organizado pelo autor. Base cartográfica: Motta (2001).

\section{A exportação do café: um caso à parte}

Em termos de padrões de localização, a atividade de exportação do café também tem interessantes singularidades, conforme mostrará nossa análise. O nível de detalhamento será maior também em relação aos recortes temporais: ao invés de trabalharmos 
apenas com dois recortes (1855 e 1900), teremos mais dois cortes intermediários (1870 e 1885). A cadeia comercial do café será vista na mesma estrutura utilizada para o restante do setor atacadista. Como anteriormente, interessam-nos tanto os agentes comerciais (vistos neste caso através dos comissários e consignatários) quanto o comércio "em grosso", representado pelos armazéns de ensaque de café. Mas antes da análise espacial propriamente dita, vejamos rapidamente alguns pontos interessantes.

Ferreira (1977) analisa a expansão e a crise dos comissários de café no Rio de Janeiro e adverte que durante o século XIX persistiram as dificuldades em relação ao seu financiamento e à sua comercialização. Para sua comercialização, a principal questão era: como estabelecer as ligações entre as zonas de plantações e o Rio de Janeiro? Imensos eram os problemas de transporte, já que se utilizavam os precários caminhos que vinham do interior e tinham seu ponto terminal no Recôncavo da Guanabara. Assim, até a inauguração das primeiras estradas de ferro, na década de 1850, todo o escoamento da produção cafeeira era feito em lombo de mulas através de perigosos caminhos. Os carregamentos desciam das respectivas áreas de produção em direção aos entrepostos comerciais de Estrela, Iguaçu e Magé - situados no fundo da Baía de Guanabara - e Mangaratiba, na Baía de Sepetiba. Mangaratiba recebia produção de São João Marcos, Piraí, Resende e Barra Mansa; Estrela recebia produção de Minas Gerais, Vassouras, Valença e Paraíba do Sul; Magé recebia produção do Oriente Fluminense (Taunay, 1945).

Desses empórios, a produção era transportada em barcos para seu destino final, o porto do Rio de Janeiro. Daí outra questão surgia, como mostra Ferreira (1977): quem receberia e venderia o produto quando este chegasse em seus pontos terminais? O percurso feito por terra até a chegada aos portos ficava por conta dos próprios fazendeiros, que possuíam escravos e tropeiros, encarregados de conduzir as tropas. Contudo, quem se encarregaria do desembarque e armazenamento, do reembarque das cargas para o Rio e, finalmente, arranjaria um comprador para a produção?

À medida que prosperavam as áreas cafeeiras, abriam-se algumas oportunidades para consumo, ainda que restritas inicialmente. Como indica Stein (1961), os fazendeiros e suas famílias começaram a adquirir alguns bens de difícil obtenção em suas regiões, tornando-se necessário o aparecimento de algum elemento que desempenhasse tal função. A execução dessas tarefas implicava em alguma experiência comercial e tempo disponível, de forma a não precipitar as vendas do café ${ }^{\text {. }}$. Para solucionar esse conjunto de problemas, começaram a surgir os primeiros intermediários que se localizavam nos portos recebedores do produto. De acordo com Ferreira (1977), inicialmente esses elementos não passavam de representantes dos fazendeiros que para eles realizavam transações, seja de venda de seus produtos, seja de compra de bens necessários. Entretanto, pouco a pouco, esses simples representantes dos fazendeiros foram adquirindo maior autonomia, passando a realizar transações por conta própria, dando início aos negócios de consignação de café.

Surgiam, originadas desses intermediários e de algumas firmas antigas de comércio na Corte, as primeiras casas comissárias de café. Nos primeiros anos da expansão cafeeira, o comissário se dedicava essencialmente à comercialização, fazendo alguns adiantamentos apenas em caráter esporádico. Entretanto, o segundo e terceiro quartéis do século XIX trouxeram uma grande expansão para o cultivo do café. Se até então os recursos familiares e pessoais completados por empréstimos esporádicos de comerciantes haviam sido suficientes, a nova dimensão que atingiam os negócios cafeeiros exigia 
Alves, V. A.

amplos investimentos. Gradativamente, os comissários passaram a atuar na esfera financeira, transformando-se em banqueiros de seus comitentes (Ferreira, 1977). Uma vez organizada uma casa comissária e estabelecida a sua clientela, a transação comercial consistia no envio do café pelo fazendeiro para a venda. Esta se processava sob a forma de consignação, ou seja, o comissário recebia o produto e o vendia nas melhores condições do mercado mediante uma comissão.

Datam da década de 1850 o aparecimento de grandes firmas pertencentes a poderosos fazendeiros já enriquecidos, criando-se uma elite de cafeicultores que acumulavam a essa função atividades comerciais e financeiras, constituindo uma burguesia comercial que controlava os principais setores econômicos. Segundo Gerson (1970:71), ia-se também o tempo dos pequenos negociantes e comerciantes das comissárias localizadas no Recôncavo da Guanabara. Com a abertura das primeiras estradas de ferro, os antigos portos escoadores viam-se gradativamente marginalizados. Assistia-se assim a transferência da concentração dos negócios cafeeiros do Vale do Paraíba na Corte do Rio de Janeiro, concretizando-se dessa forma a posição dos comissários de café, o que significava fornecimento de créditos regulares à lavoura e uma plena constituição dos mecanismos comerciais.

Na cidade do Rio de Janeiro, para que a exportação de café fosse realizada, fazia-se necessário cumprir algumas etapas (Ferreira, 1977): O café era despachado do interior da Província do Rio; chegando ao Rio, o café ficava guardado em armazéns ou em depósitos dos trapiches até que fosse enviado aviso aos comissários; o próximo passo era transportar o café para as casas comissárias, onde os sacos eram contados; a seguir, os sacos de café eram transportados para os armazéns dos ensacadores, onde eram misturadas diversas qualidades de café, fazendo o que à época se chamava de "liga"; a última etapa se relacionava com o corretor, um representante das firmas estrangeiras de importação de café da Europa e dos Estados Unidos. O corretor tinha como função procurar tipos determinados de café, segundo as exigências dos mercados externos. Assim, a atuação do exportador consistia em comprar café do ensacador através da figura do corretor. Realizados os negócios, as vendas seguiam diretamente dos armazéns dos ensacadores para o porto de embarque. Como vemos, as casas exportadoras não se ocupavam em nada com a preparação do café, resumindo-se sua atividade ao repasse dos estoques adquiridos aos mercados consumidores.

O fato é que o café foi capaz de integrar uma rede de pequenas cidades apoiada no Rio de Janeiro. Um marco neste processo é a construção da Estrada de Ferro Dom Pedro II, que substituía o transporte anteriormente feito por tropas de mulas. Na segunda metade do século XIX, são ainda realizadas melhorias das instalações físicas da área portuária do Rio de Janeiro, como: construção de cais, docas, armazéns, aterros de determinadas áreas e introdução de maquinarias nas operações de carga e descarga (Lamarão, 1991).

\section{Análise Espacial da Atividade de Exportação do Café}

Algumas permanências podem ser percebidas quando analisamos a cadeia de exportação do café entre 1855 e 1900. Primeiramente, as áreas 1 e 2 continuam mostrando grande dinamismo; com o tempo, entretanto, elas passam a perder importância para a região adjacente ao Morro de São Bento, que chamaremos aqui de área 9. 
No primeiro recorte temporal os comissários ainda estão basicamente na área 1 e, com menos força, na área 2. As maiores concentrações de comissários são as ruas de São Pedro e de Bragança, número reduzido se considerarmos o total de 47 estabelecimentos registrados no Almanak Laemmert. Nas atividades de ensaque de café a situação é outra. No mapa de 1855 já se pode visualizar um padrão mais claramente esboçado, com os armazéns já fortemente concentrados; dos 48 estabelecimentos, apenas nove estavam fora das adjacências do Morro de São Bento. Nas ruas de São Bento, Benedictinos, Municipal, São Francisco da Prainha e no largo da Prainha, portanto, se localizavam os 39 armazéns restantes. Só a primeira dessas ruas concentrava 18 estabelecimentos. A escolha pelas adjacências do Morro de São Bento estava relacionada a dois fatores principais. Em primeiro lugar, à proximidade com o largo da Prainha, que de acordo com Gerson (2000 [1955]) era, desde o início do século XIX, o principal ponto de desembarque de café da cidade. A importância dessa área, para Lamarão (1991) nos remonta mesmo aos primeiros anos do período oitocentista, quando a Prainha já havia se convertido no principal entreposto de madeiras do Rio. Ali ainda eram desembarcados açúcar, cal de marisco (material utilizado para construções) e gêneros destinados ao abastecimento da crescente população da cidade (Santos, 1934 citado por GERSON, 1970). Em segundo lugar, para os ensacadores de café, localizar-se junto aos trapiches significava, antes de tudo, reduzir sobremaneira os custos de transportes; precisamos lembrar que eram eles que conduziam o produto depois de vendê-los aos corretores - até o seu ponto final de embarque para a exportação.

Em 1870, as áreas 1, 2 e 9 continuam a ganhar força: nas duas primeiras, basicamente, localizavam-se os comissários, que acreditamos serem beneficiados com a presença de uma grande sorte de estabelecimentos atacadistas (como aqui mostramos) e varejistas. É preciso lembrar que os comissários, além da função financeira que foram adquirindo com o passar do tempo, tinham como uma de suas incumbências adquirir e repassar gêneros da cidade aos grandes cafeicultores. Entretanto, também se nota com mais clareza o início da aglomeração do comissariado na área 9, analogamente ao que verificamos em relação aos armazéns de ensaque. No caso destes últimos, dos 44 estabelecimentos, 33 se encontravam junto ao Morro de São Bento e, portanto, próximos ao largo da Prainha e aos trapiches.

Para melhor entendermos esta aglomeração de comissários e ensacadores, novamente recorremos ao referencial teórico oferecido por Corrêa (1996 [1979]), a ser explorado em duas frentes. Primeiramente, destacamos a questão da complementaridade. Como já foi tratado, os comissários e os ensacadores de café encontravam-se extremamente associados na atividade de exportação cafeeira pelo Rio de Janeiro e em alguns casos podiam-se acumular as funções de comissário e de ensacador. Assim, acreditamos que os armazéns que já se localizavam junto ao Morro de São Bento acabaram atraindo - no segundo momento - outras firmas comissárias, que junto dos ensacadores reduziam ou eliminavam os custos de transporte. É necessário lembrar que o café precisava ser levado das casas comissárias para os armazéns, onde era realizado o "beneficiamento" do produto: uma mistura de grãos chamada na época de "liga". Antes disso, porém, os comissários ainda precisavam transportar o café dos depósitos trapicheiros - onde o produto ficava armazenado quando chegava à cidade - para suas firmas. De acordo com Ferreira (1977), o café precisava ser retirado em um curto tempo, sob pena de incorrer os comissários em pesadas multas. Por essas razões, estar junto aos armazéns e aos trapiches passou a ser para os comissários, estratégia fundamental na garantia de uma maior lucratividade. 
Alves, V. A.

A outra característica descrita por Corrêa para a formação de áreas espacialmente coesas deriva do fato de muitas atividades exigirem contratos face-a-face e troca de informações. Esse fator foi inicialmente observado em relação a sedes sociais de grandes empresas. Todavia, também nos serve perfeitamente, já que todas as negociações do café eram realizadas dentro desse sistema. Segundo Ferreira (1977) havia, entre comissários e ensacadores, a existência de liames de confiança e uma prova disso se verifica em relação ao transporte do café das firmas comissárias para os armazéns: quando aí chegavam, os sacos do produto eram contados apenas em número e não quanto ao peso. A localização na área 9, portanto, mostrava-se duplamente vantajosa para as firmas comissárias, à medida que garantia a proximidade com os trapiches e com os armazéns de ensaque sem se afastar das atividades ligadas ao abastecimento das grandes fazendas. Por essa razão, esse padrão será aquele que prevalecerá da década de 1870 em diante. É o que mostra a figura 6:
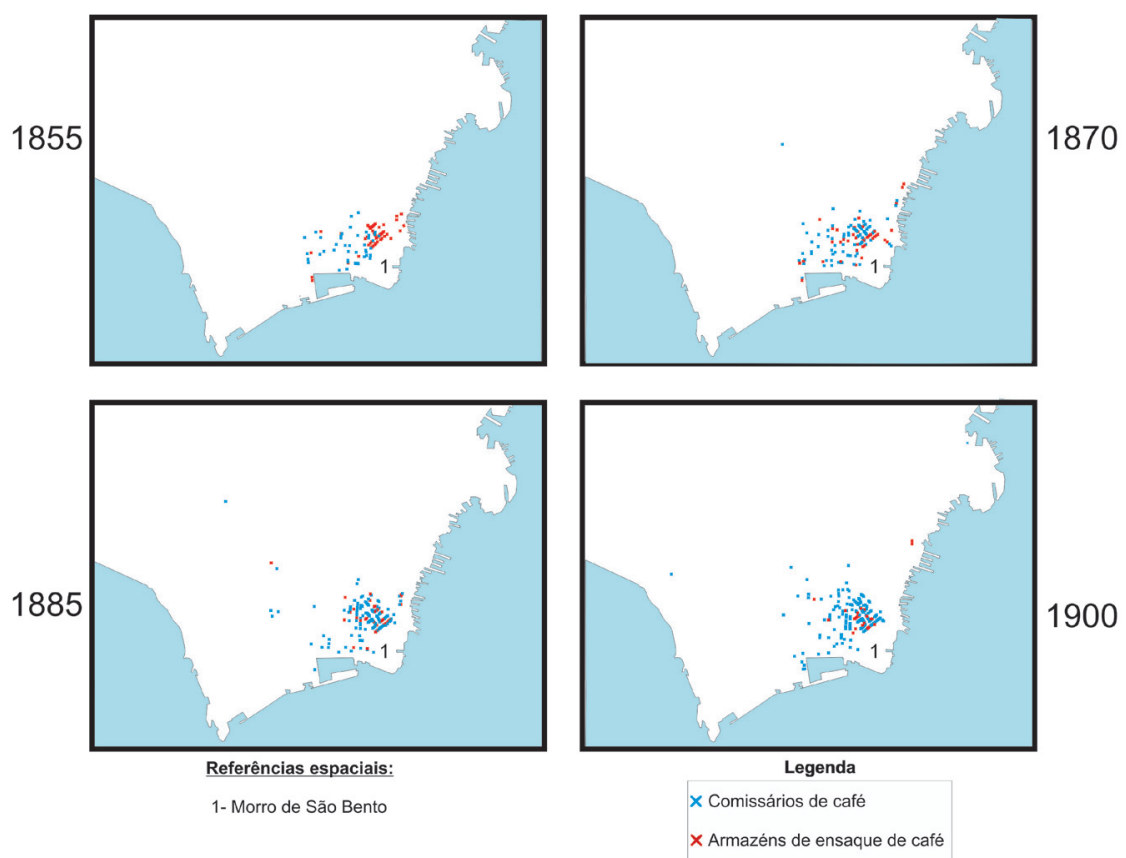

Figura 6 - Comissários e armazéns de ensaque de café (1855, 1870, 1885 e 1900). Organizado pelo autor. Base cartográfica: Motta (2001).

No terceiro recorte temporal percebe-se que praticamente não há mais armazéns de ensaque fora das imediações das ruas de São Bento, Beneditinos, Municipal e São Francisco da Prainha. A grande maioria das 117 casas comissárias existentes também aprofundam sua concentração e por isto entendemos que a partir de 1885 o processo de coesão que começou a ser verificado na década de 1870 atinge um novo estágio de desenvolvimento, se tornando ainda mais claramente visível. Voltamos à Corrêa (1996 [1979]), para quem a consequência do processo de coesão é a formação de áreas especializadas. No nosso caso, isso se confirma ainda que parcialmente ${ }^{9}$. Por fim, em 1900 a 
área especializada na exportação do café se encontra consolidada e até apresenta uma pequena expansão física, atingindo inclusive o eixo 3.

\section{Considerações Finais}

Mesmo sem contar com todos os modelos comparativos e com o conjunto original de mapas, acreditamos ter conseguido compor um quadro espacial bastante detalhado. Sem dúvida, se tornaram mais claros os padrões espaciais do comércio por atacado e os processos espaciais a ele ligados, elementos até então pouco aprofundados no estudo da evolução urbana do Rio de Janeiro.

Apresentou-se também uma visão bem ampla do comércio por atacado, cuja importância tem sido negligenciada. A despeito da dificuldade de, na prática, separar os intermediadores dos grandes depósitos, a análise do espaço urbano carioca na segunda metade do período oitocentista comprovou a coerência de estudarmos o comércio por atacado a partir de uma dupla função. Para alguns gêneros, essa divisão se tornou espacialmente muito clara.

O diálogo com a história econômica veio a comprovar a primazia da função comercial na cidade do Rio de Janeiro, mesmo com a crise de seu principal produto de exportação, o café. A análise quantitativa da Classe I (Agentes Comerciais), que apresentou o maior número dentre todas, ratificou a necessidade da intermediação comercial. Nas Classes II e III (Gêneros Alimentícios e Manufaturados, respectivamente) o aumento nos artigos importados mostrou a expansão do mercado interno carioca; no caso da primeira, em detrimento da função de exportação de gêneros tradicionais com o açúcar e o algodão.

Espacialmente, as áreas 1 e 2 foram as mais importantes na segunda metade do século XIX. Em 1900, quando a cidade já havia crescido a ponto de vencer novos sítios e ocupar freguesias mais distantes, esta tendência de concentração é mais significativa, apontando para um novo estágio no desenvolvimento da chamada área central. Todavia, ainda era grande a presença do uso residencial (aqui mensurada, por exemplo, pelos armazéns de gêneros secos e molhados); a separação entre os varejistas e atacadistas (e estes, entre agentes e depósitos) ainda também não estava totalmente clara. Apenas em alguns casos, principalmente nos gêneros da Classe IV, as concentrações de armazéns e depósitos foram mais significativas em localizações mais 'periféricas', como a área 8.

O processo espacial de coesão foi utilizado para explicar concentrações espaciais mais significativas e mostrou que não está restrito ao varejismo. No caso do café, o nível de especialização funcional foi o maior de todos os gêneros. Do ponto de vista da evolução urbana, deve ser ressaltada a presença de áreas coesas anteriormente às reformas urbanísticas do início do século XX - que aí sim transformaram forçada e definitivamente as feições do espaço urbano carioca.

Alguns detalhes da divisão territorial do trabalho não puderam ser captados como imaginávamos. Foi difícil distinguir uma divisão espacial entre as atividades de exportação e importação. Apenas no caso do café pudemos ser mais taxativos e a área 9, de fato, apresentou pouquíssima importância para outros gêneros. Aqui não apresentamos a dimensão quantitativa dos estabelecimentos do café, que indicaram uma tendência 
Alves, V. A.

de comportamento monopolista. A perda de importância do Rio de Janeiro como porto escoador de café ao longo da segunda metade do século XIX foi confirmada no caso dos comissários, que apesar de não terem apresentado a mesma tendência de diminuição numérica verificada nos armazéns de ensaque, reduziram gradativamente seu ritmo de crescimento. Mesmo assim, o Rio de Janeiro conseguiu entrar no século XX conservando boa parte de seu dinamismo comercial, inclusive com a consolidação de novas funções portuárias. É importante lembrar-se da esmagadora maioria dos intermediários não-especificados de gêneros de importação no ano de 1900. Ela ajuda a diluir a ideia que o Rio de Janeiro era exclusivamente exportador, mostrando a importância do consumo interno.

As lacunas que não foram aqui preenchidas seguem como incentivo para seguirmos com as pesquisas que, no caso do estudo histórico, têm sempre que conviver com um incômodo número de incertezas, típicas de tempos longínquos. De qualquer forma, se tudo pudéssemos saber sobre o passado, removendo-lhe todas as dúvidas, este não seria um "país estrangeiro", como adverte Lowenthal (1985).

\section{Referências Bibliográficas}

ABREU, M.A. Evolução urbana do Rio de Janeiro. Rio de Janeiro. Rio de Janeiro: IPLAN/ ZAHAR, 4 ${ }^{\mathrm{a}}$ edição, 2006 (1987).

BERNARDES, L. Evolução da paisagem urbana do Rio de Janeiro até o início do século XX. Boletim Carioca de Geografia. Rio de Janeiro, 1959.

BRAUDEL, F. Civilização material, economia e capitalismo (séculos VX-VXIII). São Paulo: Matins Fontes, 1996.

CHRISTALLER, W. Central places in southern Germany. Englewood Cliffs: Prentice-Hall, 1966 (1933).

CORRÊA, R.L. Processos espaciais e a cidade. Trajetórias geográficas. Rio de Janeiro: Bertrand Brasil, 1996 (1979).

Comércio e espaço: uma retrospectiva e algumas questões. Textos LAGET, Série Pesquisa e Ensino. ${ }^{\circ}$ 2. Rio de Janeiro: Universidade Federal do Rio de Janeiro, Laboratório de Gestão do Território, 2000.

ESTAVILLE, L. Organizing time in Historical Geography. In: BROOKS GREEN, D. (Ed.). Historical geography: a methodological portrayal. Maryland: Rowman \& Littlefield Publishers, p.310-323, 1991.

FERREIRA, M. A crise dos comissários do café do Rio de Janeiro. Dissertação de Mestrado/História. Niterói: UFF, 1977. 
GALVÃO, M.C.C. Focos sobre a Questão Ambiental no Rio de Janeiro. In: ABREU, M. A. (Org.) Natureza e Sociedade no Rio de Janeiro. Rio de Janeiro: Biblioteca Carioca, 1992.

GERSON, B. O ouro, o café e o Rio. Rio de Janeiro: Livraria Brasiliana Editora, 1970.

HEIDINGSFIELD, M.S.; BLANKENSHIP, A.B. Marketing: comercialização. Rio de Janeiro: FUNDO CULT, 1957.

LAMARÃO, S.T.N. Dos trapiches ao porto: um estudo sobre a área portuária do Rio de Janeiro. Rio de Janeiro: Prefeitura da Cidade do Rio de Janeiro / Secretaria Municipal de Cultura, Turismo e Esportes, 1991.

LOWENTHAL, D. The Past Is a Foreign Country. Cambridge: Cambridge University Press, 1985.

MOTTA, M.P. O centro da cidade do Rio de Janeiro no século XIX: reflexões sobre a noção de área central. Dissertação de Mestrado / PPGG. Rio de Janeiro: UFRJ, 2001.

RIBEIRO FILHO, V. A área central e sua dinâmica: uma discussão. Revista Sociedade e Natureza, v. 16, n. 31. Uberlândia, 2004.

STEIN, S. Grandeza e decadência do café no Vale do Paraíba. São Paulo: Brasiliense, 1961.

STROHAECKER, T M. A zona periférica ao centro: uma revisão bibliográfica. Revista Brasileira de Geografia n $^{\circ}$ 50, 1988.

TAUNAY, A.E. Pequena história do café no Brasil. Rio de Janeiro: Departamento Nacional do Café, 1945.

VANCE JR., J. The merchant's world: the geography of wholesaling. New Jersey: Foudantions of Economic Geography Series, 1970.

WEBER, M. A gênese do capitalismo moderno. São Paulo: Ática, 2006.

Recebido em: 16/07/2012

Aceito em: 28/12/2012

\footnotetext{
1 "A Geografia do Comércio Atacadista Carioca (1855-1900)" teve como orientador o Prof. Dr. Roberto Lobato Corrêa, que assumiu tal esforço após o afastamento de Mauricio Abreu. A ele agradeço pela ajuda de sempre. 
Alves, V. A.

\footnotetext{
${ }^{2}$ Artigo aceito pela Revista Cidades no primeiro semestre de 2012.

${ }^{3}$ Para algumas considerações históricas sobre o surgimento do comércio atacadista e sua separação dos varejistas, ver: Webber (2006) e Braudel (1996).

${ }^{4}$ Para o diálogo com a história econômica, utilizou-se três grupos de documentos: "Relatórios do Ministério da Fazenda"; "Importação e exportação: movimento marítimo, cambial e do café da República dos Estados Unidos do Brazil" e "Mappas Estatísticos da Navegação e do Commercio Marítimo do Porto do Rio de Janeiro".

${ }^{5}$ Poderíamos também considerar o comércio atacadista como um 'sub-setor' do setor terciário. Seguirei, entretanto, a denominação utilizada na Dissertação de Mestrado.

${ }^{6}$ Para uma revisão bibliográfica sobre o conceito de área central, ver o trabalho de Ribeiro Filho (2004).

${ }^{7}$ A melhor revisão bibliográfica sobre a evolução do conceito de Zona Periférica do Centro e de outros a ele ligados ainda é o trabalho de Strohaecker (1988).

${ }^{8}$ Além das dificuldades apontadas, pode-se acrescentar as grandes distâncias que separavam as propriedades dos locais de venda e as dificuldades dos fazendeiros em se afastar da administração de suas fazendas. Uma ida ao Rio de Janeiro, nas condições da época significava várias semanas de ausência, como indica Stein (1961).

${ }^{9}$ Como vimos, no eixo 9 também se verificava a presença de outros gêneros; é mais claramente o caso de depósitos de açúcar, de máquinas para indústria e mesmo de agentes diversos. Por isso, e pelo fato de que muitos agentes e armazéns trabalhavam com mais de um gênero ao mesmo tempo, é difícil falar em uma 'especialização total'.
} 